\title{
Improved mortality after STEMI over two decades
}

\author{
Jon M Kristjansson ${ }^{1,2^{*}}$, Bergros K Johannesdottir ${ }^{1}$, Thorarinn Gudnason ${ }^{2}$, Karl Andersen ${ }^{1,2}$ \\ From Danish Society for Emergency Medicine: Research Symposium 2010 \\ Roskilde, Denmark. 20-21 May 2010
}

\section{Background}

Over the past two decades the treatment of ST-elevation myocardial infarction (STEMI) has changed significantly. We set out to investigate the effect of these changes on one-year mortality from STEMI.

\section{Methods}

Data was collected on all hospital admissions for STEMI in Reykjavik, Iceland during the calendar years of 1986, 1996 and 2006. Patients were followed for one year regarding all cause death and hospital readmission for cardiac causes. The outcome was related to changes in the use of reperfusion strategies and medication at hospital discharge.

\section{Results}

A total of 335 patients in 1986, 351 in 1996 and 178 patients in 2006 comprise the total study population of 864 STEMI patients. In addition $25(6,9 \%)$ patients died within the first 24 hours of hospital admission in 1986, $33(15,6 \%)$ in 1996 and $5(2,7 \%)$ in 2006. One-year mortality decreased from $26.3 \%$ in 1986 and $19.7 \%$ in 1996 to $12.9 \%$ in 2006 ( $\mathrm{p}=0.001$ ). Cox proportional hazard analysis showed aspirin (HR 0.29), the use of reperfusion therapy (HR 0.51) and beta blockers at hospital discharge (HR 0.53) to be the strongest factors to explain the mortality reduction while the use of diuretics (HR 1.42) and age (HR 1.06) were related to increased one year mortality.

\section{Conclusion}

The reduction in 1-year mortality after myocardial infarction during the last two decades is explained by improved medical management with aspirin, beta blockers and aggressive reperfusion therapy. Diuretic therapy,

* Correspondence: jonmkr@lsh.is

'University of Iceland, Faculty of Medicine, Iceland

Full list of author information is available at the end of the article reflecting congestive heart failure, and increased age have negative effects on survival.

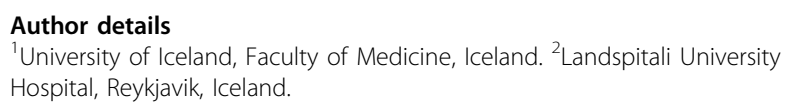

Published: 17 September 2010

doi:10.1186/1757-7241-18-S1-P15

Cite this article as: Kristjansson et al: Improved mortality after STEMI over two decades. Scandinavian Journal of Trauma, Resuscitation and Emergency Medicine 2010 18(Suppl 1):P15.
Submit your next manuscript to BioMed Central and take full advantage of:

- Convenient online submission

- Thorough peer review

- No space constraints or color figure charges

- Immediate publication on acceptance

- Inclusion in PubMed, CAS, Scopus and Google Scholar

- Research which is freely available for redistribution

Submit your manuscript at www.biomedcentral.com/submit 